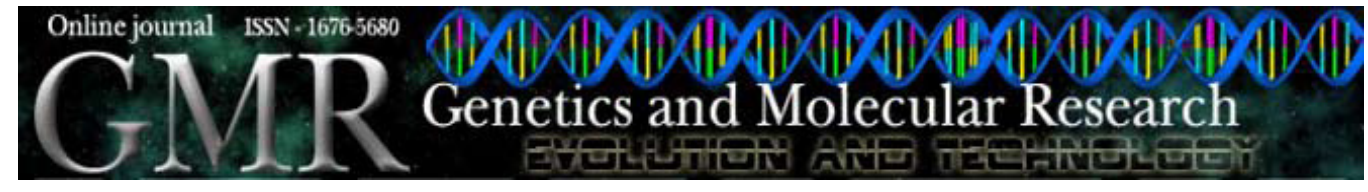

\title{
Trap-nesting bees (Hymenoptera: Apoidea) in forest fragments of the State of São Paulo, Brazil
}

\author{
A.L. Gazola and C.A. Garófalo \\ Departamento de Biologia, Faculdade de Filosofia, \\ Ciências e Letras de Ribeirão Preto, Universidade de São Paulo, \\ Ribeirão Preto, SP, Brasil \\ Corresponding author: C.A. Garófalo \\ E-mail: garofalo@ffclrp.usp.br
}

Genet. Mol. Res. 8 (2): 607-622 (2009)

Received December 12, 2008

Accepted January 26, 2009

Published May 26, 2009

\begin{abstract}
We studied the community ecology of trap-nesting bees in two forest fragments of the State of São Paulo, Brazil, during two years, utilizing bamboo canes and tubes made of black cardboard as trap nests. The traps were inspected once a month with an otoscope. One hundred and fifteen nests were obtained at Estação Ecológica de Paulo de Faria, Paulo de Faria (EEPF). These included nine species belonging to five genera and two families. At Santa Cecília Farm (SCF), 12 species belonging to seven genera and three families built 392 nests. Natural enemies reared from nests of both areas included Hymenoptera, Diptera and Coleoptera. Species richness was similar between the areas but the communities differed considerably in species composition. The higher diversity found at EEPF was due to more even distribution of the species. No difference was observed between the numbers of nests built in each year in each area. Although the species richness was lower in the cool/dry season of both years at SCF, and in the first year at EEPF, the nesting frequencies did not differ between seasons for both the overall community but for each of the most abundant species. No annual fluctuation in the frequencies of nesting was observed. As
\end{abstract}


temperature and precipitation were not found to be significantly different between the two years of study in each area, we concluded that climatic stability resulted in population stability.

Key words: Apoidea; Solitary bees; Community; Species diversity; Trap-nests; Parasitism

\section{INTRODUCTION}

Biological inventories are basic tools for initial surveys of biological diversity, as well as for monitoring alterations of different components of this diversity, as a consequence of changes in environmental conditions, due to natural processes or due to human activities (Lewinsohn et al., 2001). Habitat fragmentation is considered to be one of the greatest threats to biological diversity (Davies et al., 2000), and due to increasing global habitat destruction, studies of species diversity are of vital importance for understanding biological communities and their conservation (Purvis and Hector, 2000). In studies made in Brazil with solitary bee species that nest in preexisting cavities, the use of trap-nests as a technique for sampling of species has provided important information not only on the occurrence of species in a habitat (Camillo et al., 1995; Garófalo, 2000; Morato and Campos, 2000; Viana et al., 2001; Aguiar and Martins, 2002; Alves-dos-Santos, 2003; Aguiar et al., 2005; Loyola and Matins, 2006; Buschini, 2006) but also on the nesting biology of those species (Garófalo et al., 1993; Pereira et al., 1999; Morato et al., 1999; Jesus and Garófalo, 2000; Alvesdos-Santos et al., 2002; Gazola and Garófalo, 2003; Aguiar and Garófalo, 2004; Zillikens and Steiner, 2004; Camillo, 2005; Aguiar et al., 2006; Couto and Camillo, 2007).

Data on communities of trap-nesting bees and wasps and their natural enemies have been used in research on habitat quality (Frankie et al., 1998; Tscharntke et al., 1998), the effects of habitat fragmentation and of landscape complexity on community composition and predatory-prey interactions (Morato and Campos, 2000; Morato, 2001; Steffan-Dewenter, 2002; Kruess and Tscharntke, 2002; Klein et al., 2006; Tylianakis et al., 2006) and how urban environments can support such insects (Tommasi et al., 2004; Zanette et al., 2005).

Although Brazil has a very rich fauna of solitary bees and many studies with such bees have been made in the last years, there is still very little biological information available. We examined the species richness, diversity and abundance of cavity-nesting bees in two semidecidual forest fragments of the State of São Paulo, Estação Ecológica de Paulo de Faria (EEPF), Paulo de Faria, located in the northern region, and Santa Cecília Farm (SCF), Patrocínio Paulista, located in the northeastern region of the state. Both fragments are of great importance since they are considered the last remnants of the forest that originally covered the interior of the state. This is part of a larger study on communities of bees nesting in preexisting cavities in forest fragments of the State of São Paulo, Brazil.

\section{MATERIAL AND METHODS}

\section{Areas of study}

Trapping was done at the EEPF, in the municipality of Paulo de Faria, and SCF, in 
the municipality of Patrocínio Paulista (20 $46^{\prime}$ 'S and $\left.47^{\circ} 14^{\prime} \mathrm{W}\right)$, State of São Paulo. The EEPF (19 $55^{\prime}-19^{\circ} 58^{\prime} \mathrm{S}$ and $\left.49^{\circ} 31^{\prime}-49^{\circ} 32^{\prime} \mathrm{W}\right)$ is located along one of the banks of the Rio Grande, in the northern part of the state, with altitudes ranging from 400 to $495 \mathrm{~m}$. Its 435.73 ha are covered by a semideciduous forest. The local climate has two well-defined seasons, a cool and dry season extending from April to September, with the mean monthly temperature ranging from 19.8 to $31.7^{\circ} \mathrm{C}$ and precipitation from 0 to $63.5 \mathrm{~mm}$, and a hot and wet season extending from October to March, with the mean monthly temperature ranging from 23.7 to $31.3^{\circ} \mathrm{C}$ and precipitation from 58.2 to $382.9 \mathrm{~mm}$. The SCF $\left(20^{\circ} 46^{\prime} \mathrm{S}\right.$ and $47^{\circ} 61^{\prime} \mathrm{W}$ ) is located in the northeast region of the state, with altitudes ranging from 800 to $1040 \mathrm{~m}$. The farm has an area of $96 \mathrm{ha}$, covered by a semideciduous forest surrounded by cultivated land and/or pasture and by "cerrado" (savanna). Similar to EEPF, the local climate has a cool and dry season extending from April to September, with the mean monthly temperature ranging from 17.4 to $22.3^{\circ} \mathrm{C}$ and precipitation from 0.2 to 122.9 $\mathrm{mm}$, and a hot and wet season extending from October to March, with the mean monthly temperature ranging from 21.1 to $23.3^{\circ} \mathrm{C}$ and precipitation from 29.3 to $363.8 \mathrm{~mm}$.

\section{Methods}

As described by Camillo et al. (1995), the trap-nests used consisted of hollow bamboo canes, which were cut so that a nodal septum closed one end of the cane. We also used black cardboard tubes, with one end closed with the same cardboard material. The bamboo canes had variable length and their internal diameter ranged from 0.4 to 2.9 $\mathrm{cm}$, although all sizes were not equally represented. The tubes were of three sizes (length $\mathrm{x}$ internal diameter): $8.5 \times 0.8 \mathrm{~cm}$ (= large tubes), $8.5 \times 0.7 \mathrm{~cm}$ (= medium tubes) and $5.8 \times 0.6 \mathrm{~cm}$ (= small tubes). These tubes were inserted into horizontal holes drilled into wooden plates $(30.0 \times 15.0 \times 4.0 \mathrm{~cm}$ for small tubes and $30.0 \times 15.0 \times 7.0 \mathrm{~cm}$ for medium and large tubes). At EEPF, a total of 843 canes, eight plates containing 220 small tubes, two plates containing 80 medium tubes, and two plates containing 54 large tubes were placed along steel shelves put in a shed built in the study area. At SCF, two sampling sites were established: one in a farm shed and the other $260 \mathrm{~m}$ away, in the interior of the forest. At the farm shed, two plates containing 110 small tubes and two plates containing 40 large tubes were hung on the external walls, and 616 canes, in bundles of 10-15 units, were placed along the wood structure of the roof. In the forest were placed four plates with 55 small tubes each, four plates with 40 large tubes each, and 160 canes. In order to protect the trap-nests from the sun and the rain, the canes were put into six PVC tubes with a length of $25 \mathrm{~cm}$ and a diameter of $10 \mathrm{~cm}$, and each plate received a small cover of hard plastic. The PVC tubes and the plates were hung from trees and positioned 1.5-2.0 $\mathrm{m}$ above the ground.

The trap-nests were inspected once a month from January 1998 to December 1999 at EEPF, and from March 2000 to February 2002 at SCF. Each inspection was made with the aid of an otoscope. When traps contained completed nests, they were collected and replaced with empty ones. The traps occupied by females were marked and left at their original places. If completed, such nests were taken to the laboratory at the next inspection. In the laboratory, each trap-nest was introduced into a transparent glass or plastic tube, 4.0-5.0 $\mathrm{cm}$ longer than the trap, with one end closed with a cork. As adults emerged 
into the glass/plastic tube, the trap was removed and the individuals were collected. The nests were kept at room temperature and observed daily until the adults emerged. A few days after the last emergence from any given nest occurred, the nest was opened and its contents analyzed. Cells and nests from which nothing emerged were also opened, and the cause and stage of mortality were recorded. Voucher specimens of bees are deposited in the Entomological Collection of the Departamento de Biologia da Faculdade de Filosofia, Ciências e Letras de Ribeirão Preto, University of São Paulo.

\section{Statistical analysis}

The number of nests was used as a measure of species abundance. Rarefaction analyses from a standardized number of nests were made to measure species richness using EcoSim (Gotelli and Entsminger, 2004). Using these data, we constructed rarefaction curves (Hulbert, 1971; Simberloff, 1972) using a Monte Carlo permutation method. To estimate the number of species for $\mathrm{k}$ nests, $\mathrm{k}$ nests were randomly withdrawn from the sample and the observed number of species was registered. That procedure was repeated 1000 times. The rarefaction curves allowed comparing the species richness between the areas and between the seasons in the same area. Significant differences in the species richness between areas and seasons were based on the confidence intervals provided by EcoSim (Gotelli and Entsminger, 2004). To compare diversity between areas, diversity for each of them was calculated from the number of emerged individuals, using the Shannon-Wiener index. A posteriori statistical $t$-test (Hutcheson, 1970) was calculated to analyze the null hypothesis of no difference between the Shannon-Wiener values (Magurran, 2004). Species evenness was estimated by means of Pielou's index (J') (Pielou, 1966). Sorensen's index was calculated between areas to obtain an estimate of similarity in species composition (Ludwig and Reynolds, 1988), and the Morisita's index was used to analyze the quantitative similarity between areas (Morisita, 1959) based on relative abundance of the nests. Natural enemies were excluded from analyses, as their diversity is partially dependent on available host species.

Statistical tests follow Zar (1984) and were performed by using the statistical package SigmaStat for Windows (1994 - Jandel Corporation, San Rafael, CA, USA). The Mann-Whitney test and the Student $t$-test were utilized to compare the total number of nests built per year in each area, the number of nests built in each season, the frequencies of nesting per year in each area and in each season by the most abundant species, and the climatic conditions of the two areas.

\section{RESULTS}

\section{Abundance and species richness}

At EEPF, 330 individuals were reared from 115 trap-nests, representing two families, Apidae and Megachilidae, five genera, Centris, Tetrapedia, Eufriesea, Euglossa, and Megachile, and nine species. The most abundant species were Centris analis (63 nests and 135 individuals) and Centris tarsata (23 nests and 100 individuals) and the rare species (with one or two nests) accounted for four of the nine species (Table 1). At SCF, 916 indi- 
viduals emerged from 392 nests established at the farm shed and 21 nests were established inside the forest. The individuals belong to three families, Apidae, Megachilidae and Colletidae, seven genera, Centris, Tetrapedia, Euglossa, Megachile, Anthodioctes, Colletes, and Saranthidium, and 12 species. The most abundant species were C. analis (280 nests and 556 individuals) and Tetrapedia diversipes (101 nests and 275 individuals; Table 1).

Although species of the genera Centris and Megachile have been found in both sites, we only found Centris sp and Megachile sp in EEPF. Among the 12 species sampled at SCF, six species occurred exclusively in that area and three were found only inside the forest (Table 1).

\begin{tabular}{|c|c|c|c|c|c|}
\hline \multirow[t]{2}{*}{ Species } & \multirow[t]{2}{*}{ Year } & \multicolumn{2}{|c|}{ Number of nests by site } & \multicolumn{2}{|c|}{ Number of emerged individuals } \\
\hline & & EEPF & SCF & EEPF & SCF \\
\hline \multicolumn{6}{|l|}{ Apidae } \\
\hline \multirow{2}{*}{ Centris analis (Fabricius) } & $1 \mathrm{st}$ & 42 & $147(+1)$ & 95 & $296(+1)$ \\
\hline & 2nd & 21 & $130(+2)$ & 40 & $256(+3)$ \\
\hline \multirow[t]{2}{*}{ Centris tarsata Smith } & $1 \mathrm{st}$ & 6 & 8 & 34 & 28 \\
\hline & 2nd & 17 & 1 & 66 & 9 \\
\hline Centris sp & 2nd & 1 & & 4 & \\
\hline Centris labrosa & 2nd & & $1(+4)$ & & $3(+8)$ \\
\hline \multirow[t]{2}{*}{ Tetrapedia diversipes } & $1 \mathrm{st}$ & 1 & $38(+1)$ & 4 & $99(+3)$ \\
\hline & 2 nd & 6 & $59(+3)$ & 29 & $168(+5)$ \\
\hline \multirow[t]{2}{*}{ Tetrapedia rugulosa } & $1 \mathrm{st}$ & & 1 & & 1 \\
\hline & 2nd & & (1) & & (1) \\
\hline Tetrapedia curvitarsis & $1 \mathrm{st}$ & & 1 & & 3 \\
\hline Eufriesea surinamensis & 2nd & 2 & & 2 & \\
\hline Eufriesea auriceps & $1 \mathrm{st}$ & 1 & & 5 & \\
\hline \multirow[t]{2}{*}{ Euglossa townsendi } & $1 \mathrm{st}$ & 2 & & 15 & \\
\hline & 2nd & & 1 & & 1 \\
\hline \multicolumn{6}{|l|}{ Megachilidae } \\
\hline \multirow[t]{2}{*}{ Megachile xanthoptera } & $1 \mathrm{st}$ & 5 & & 13 & \\
\hline & 2 nd & 2 & $1(+3)$ & 2 & $1(+6)$ \\
\hline \multirow[t]{2}{*}{ Megachile sp } & $1 \mathrm{st}$ & 7 & & 18 & \\
\hline & 2 nd & 2 & & 3 & \\
\hline Megachile (Pseudocentris) sp & 2nd & & (1) & & (3) \\
\hline Saranthidium marginatum & 2nd & & (1) & & (4) \\
\hline \multirow[t]{2}{*}{ Anthodioctes megachiloides } & $1 \mathrm{st}$ & & (2) & & (5) \\
\hline & 2nd & & (2) & & (2) \\
\hline \multicolumn{6}{|l|}{ Colletidae } \\
\hline \multirow[t]{2}{*}{ Colletes rufipes } & $1 \mathrm{st}$ & & 3 & & 3 \\
\hline & 2 nd & & 1 & & 7 \\
\hline Total & & 115 & $392(+21)$ & 330 & $875(+41)$ \\
\hline
\end{tabular}

Numbers in parentheses correspond to nests established inside the forest at SCF.

In addition to the nine bee species nesting at EEPF, individuals of seven parasite species were also reared from the nests. These species belong to the Megachilidae (three species) and Apidae (two species, Hymenoptera, Apoidea), Leucospidae (one species, Hy- 
menoptera, Chalcidoidea), and Bombyliidae (one species, Diptera). Only Coelioxys aff. uhleri was associated with more than one host species (C. analis and C. tarsata), and $C$. tarsata was the host species attacked by the largest number of natural enemies (three species). At SCF, 13 species of natural enemies were found associated with eight host species. Anthrax (Diptera, Bombyliidae) and Coelioxys (Hymenoptera, Megachilidae) were the genera with the highest number of host species, and $C$. analis and T. diversipes were the host species attacked by the highest number of natural enemies, eight and six, respectively (Table 2).

Table 2. Natural enemies of trap-nesting bees at Estação Ecológica de Paulo de Faria (EEPF) and at Santa Cecília Farm (SCF) during two years of study.

\begin{tabular}{|c|c|}
\hline Host species & Natural enemies and areas of occurrence \\
\hline \multicolumn{2}{|l|}{ Apidae } \\
\hline Centris analis & $\begin{array}{l}\text { Coelioxys aff. uhleri (Hymenoptera: Megachilidae) (EEPF and SCF); } \\
\text { Coelioxys (Cyrtocoelioxys) sp (Hymenoptera: Megachilidae) (SCF); } \\
\text { Leucospis cayennensis (Hymenoptera: Leucospidae) (EEPF and SCF); } \\
\text { Anthrax macquarti (Diptera: Bombyliidae) (SCF); } \\
\text { Nemognatha sp (Coleoptera: Meloidae) (SCF); } \\
\text { Leucospis sp (Hymenoptera: Leucospidae) (SCF); } \\
\text { Anthrax sp (Diptera: Bombyliidae) (SCF); } \\
\text { Coelioxys sp (Hymenoptera: Megachilidae) (SCF) }\end{array}$ \\
\hline Centris tarsata & $\begin{array}{l}\text { Coelioxys (Cyrtocoelioxys) sp (SCF); } \\
\text { Mesocheira bicolor (Hymenoptera: Apidae) (EEPF and SCF); } \\
\text { Coelioxys aff. uhleri (EEPF); } \\
\text { Anthrax oedipus (Diptera: Bombyliidae) (EEPF) }\end{array}$ \\
\hline Tetrapedia diversipes & $\begin{array}{l}\text { Leucospis cayennensis }(\mathrm{SCF}) \text {; } \\
\text { Anthrax oedipus (SCF); } \\
\text { Coelioxoides exulans (Hymenoptera: Megachilidae) (SCF); } \\
\text { Anthrax aquilus (Diptera: Bombyliidae) (SCF); } \\
\text { Anthrax hylaios (Diptera: Bombyliidae) (SCF); } \\
\text { Coelioxoides waltheriae (Hymenoptera: Megachilidae) (SCF) }\end{array}$ \\
\hline Tetrapedia rugulosa & Anthrax oedipus (SCF) \\
\hline Tetrapedia curvitarsis & Leucospis cayennensis (SCF) \\
\hline Tetrapedia $\mathrm{sp}$ & Coelioxoides waltheriae (SCF) \\
\hline Eufriesea $\mathrm{sp}$ & Exaerete dentata (Hymenoptera: Apidae) (EEPF) \\
\hline Euglossa sp & Hoplostelis bilineolata (Hymenoptera: Megachilidae) (EEPF) \\
\hline Centris sp & $\begin{array}{l}\text { Coelioxys aff. uhleri (SCF); } \\
\text { Coelioxys (Cyrtocoelioxys) sp (EEPF) }\end{array}$ \\
\hline \multicolumn{2}{|l|}{ Megachilidae } \\
\hline Megachile xanthoptera & $\begin{array}{l}\text { Leucospis } \mathrm{sp}(\mathrm{SCF}) \\
\text { Coelioxys spatuliventer (Hymenoptera: Megachilidae) (EEPF); } \\
\text { Anthrax } \mathrm{sp}(\mathrm{SCF})\end{array}$ \\
\hline Unknown hosts* & $\begin{array}{l}\text { Leucospis cayennensis }(\mathrm{SCF}) \\
\text { Anthrax oedipus }(\mathrm{SCF})\end{array}$ \\
\hline
\end{tabular}

*Were not identified because all brood cells had been parasitized.

Rarefaction analysis showed that the species richness were similar in the areas. At EEPF, the richness standardized for $\mathrm{N}=115$ nests was nine species $(9-9,95 \%$ confidence interval) and at SCF, the richness was 7.6 species $(5-10,95 \%$ confidence interval; Figure 1). The Shannon-Wiener index revealed a higher diversity for EEPF $\left(\mathrm{H}^{\prime}=1.56\right)$ than that observed for $\mathrm{SCF}\left(\mathrm{H}^{\prime}=1.05, \mathrm{t}=8.2 ; \mathrm{P}<0.05\right)$. Similarly, the species evenness at EEPF $(\mathrm{J}$ ' $=0.71)$ was higher than that observed at $\operatorname{SCF}\left(\mathrm{J}^{\prime}=0.42\right)$. In relation to presence-absence 
of species in the two areas, Sorensen's index showed a similarity smaller than $50 \%\left(\mathrm{~S}_{\mathrm{S}}\right.$ $=0.48$ ) while Morisita's index, based on relative abundance of the nests, revealed a high similarity between the areas $\left(\mathrm{C}_{\mathrm{H}}=0.89\right)$.

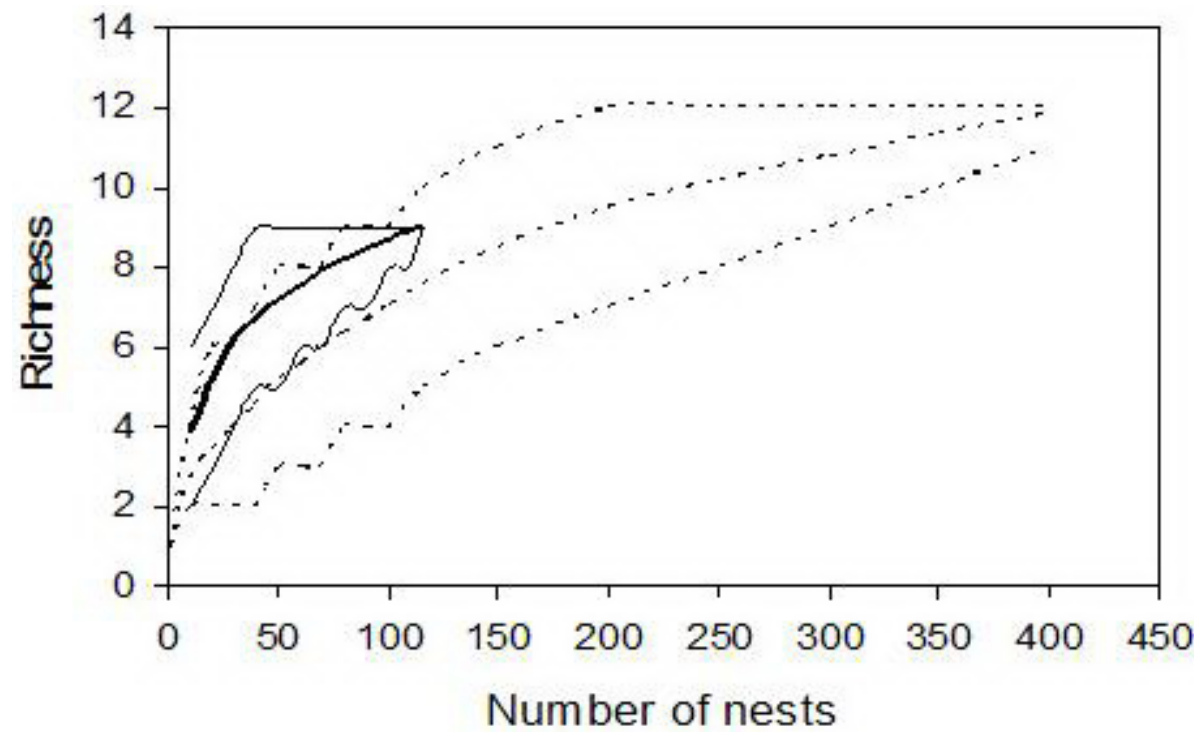

Figure 1. Rarefaction curves of trap-nests occupied by bee species at Estação Ecológica de Paulo de Faria (EEPF), Paulo de Faria, SP, from January 1998 to December 1999, and Santa Cecília Farm (SCF), Patrocínio Paulista, SP, from March 2000 to February 2002. Continuous line = EEPF; Dashed line $=$ SCF.

\section{Comparison between years}

Among the 115 nests established by nine species at EEPF, 64 nests were constructed by seven species in the first year and 51 nests were constructed by seven species in the second year. No significant difference was observed between the total number of nests made in the first and second years (Mann-Whitney test; $Z=0.26 ; P=0.792$ ) or between the frequencies of nesting by $C$. analis in each year (Mann-Whitney test; $\mathrm{Z}=0.94$; $\mathrm{P}=0.344)$. Although the number of species was similar for the two years, E. auriceps and E. townsendi only nested the first year while Centris sp and E. surinamensis were only sampled in the second year (Table 1). At SCF, of the 413 nests collected, 202 nests were made in the first year and 211 nests were established in the second year; these frequencies were not significantly different (Mann-Whitney test; $\mathrm{Z}=0.05 ; \mathrm{P}=0.953$ ). Of the 12 species that occupied the traps, seven species were sampled in both years and the five remaining species were only found in the second year (Table 1). The frequencies of nesting by $C$. analis and $T$. diversipes observed in each year were not significantly different (Mann-Whitney tests; $\mathrm{Z}=-0.28 ; \mathrm{P}=0.772$ and $\mathrm{Z}=-0.61 ; \mathrm{P}=0.540$, respectively). Species accumulation curves show that at EEPF the species accumulation was faster than at SCF in the first year, but subsequently more species nested at SCF (Figure 2). 


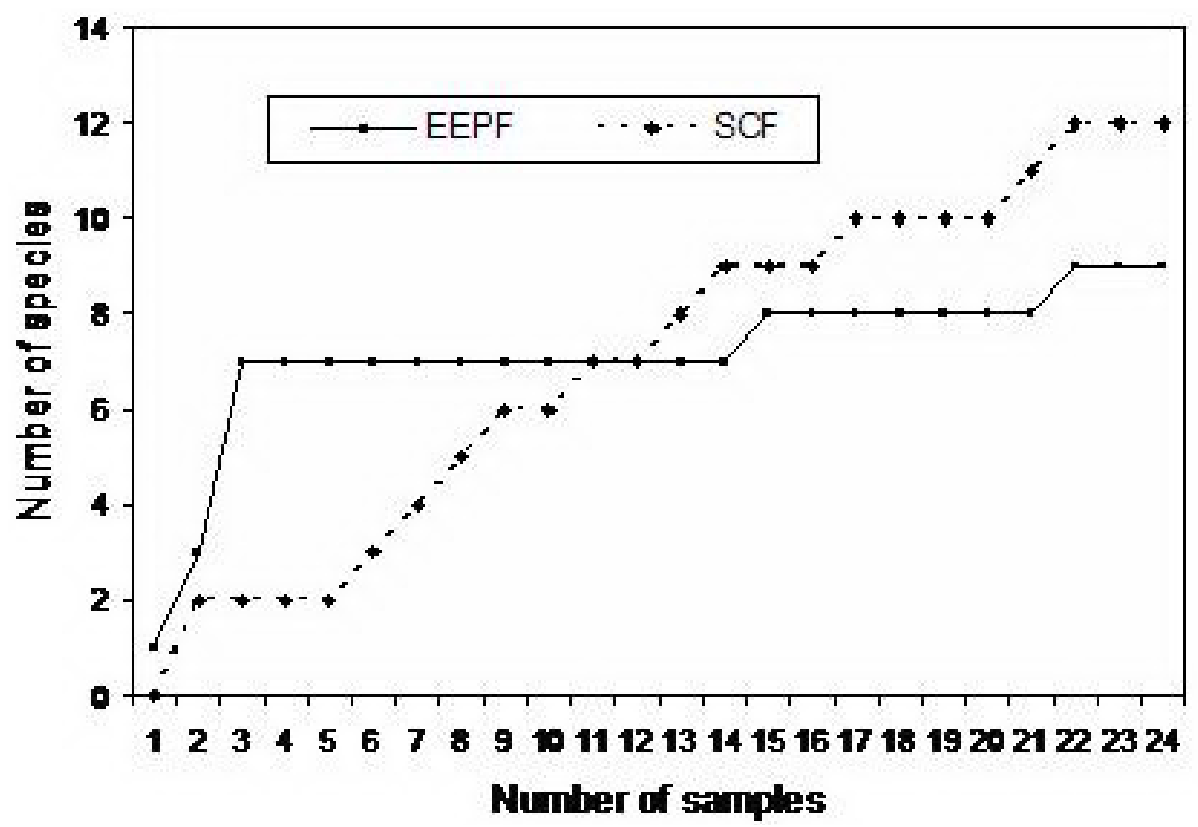

Figure 2. Cumulative number of bee species that nested in the traps at Estação Ecológica de Paulo de Faria (EEPF), Paulo de Faria, SP, from January 1998 to December 1999, and Santa Cecília Farm (SCF), Patrocínio Paulista, SP, from March 2000 to February 2002.

\section{Comparison between seasons}

At EEPF, the hot/wet and cool/dry seasons had significantly different precipitation in both years (Mann-Whitney tests; $\mathrm{Z}=2.88 ; \mathrm{P}=0.003$ and $\mathrm{Z}=2.72 ; \mathrm{P}=0.006$, for the first and second years, respectively) while the temperature was similar in the two seasons during the second year (Mann-Whitney test; $\mathrm{Z}=0.96 ; \mathrm{P}=0.336$ ) but significantly different between them in the first season (Mann-Whitney test; $\mathrm{Z}=2.72 ; \mathrm{P}=0.006$ ). These two climatic variables were similar in the hot/wet season of the two years $(\mathrm{t}=0.70 ; \mathrm{P}=0.500$ and $\mathrm{t}=0.86 ; \mathrm{P}=0.410$, for temperature and precipitation, respectively) as well as in the cool/dry seasons $(\mathrm{t}=-1.19 ; \mathrm{P}=0.262$ and $\mathrm{t}=0.73 ; \mathrm{P}=0.478$, for temperature and precipitation, respectively). In the first year, the standardized richness by rarefaction for 28 nests was higher (seven species) for the hot/wet season (7-7, 95\% confidence interval) than that found (2.9 species) for the cool/dry season (3-3, 95\% confidence interval; Figure 3). In the second year, however, the standardized richness for 23 nests was similar between the seasons: five species $(5-5,95 \%$ confidence interval) for the hot/wet season and 5.7 species $(5-6,95 \%$ confidence interval) for the cool/dry season (Figure 4). No significant difference between the number of nests built in each season in both years was observed $(\mathrm{t}$ $=0.29 ; \mathrm{P}=0.77$, for hot/wet and cool/dry seasons of the first year, and $\mathrm{t}=0.25 ; \mathrm{P}=0.802$, for those seasons in the second year). 


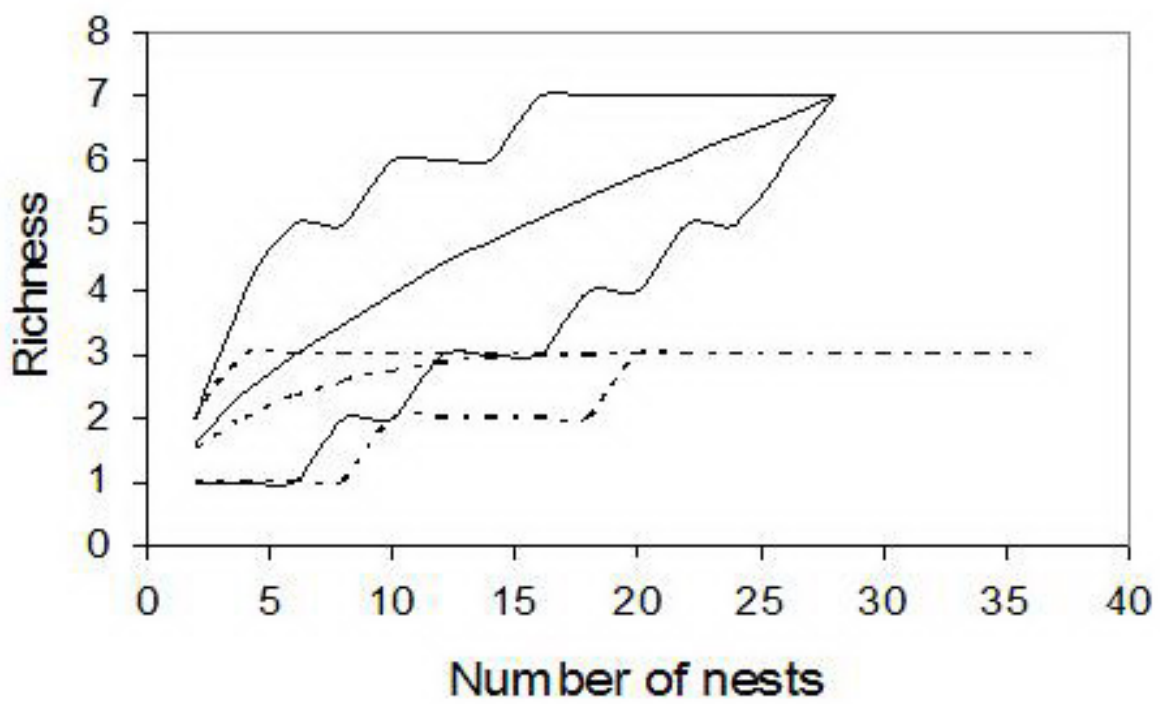

Figure 3. Nest-based rarefaction curves for the hot/wet and cool/dry seasons of the first year of study at Estação Ecológica de Paulo de Faria, Paulo de Faria, SP. Comparisons were made for 28 nests, 95\% confidence interval. Continuous line $=$ hot $/$ wet season; Dashed line $=$ cool $/$ dry season.

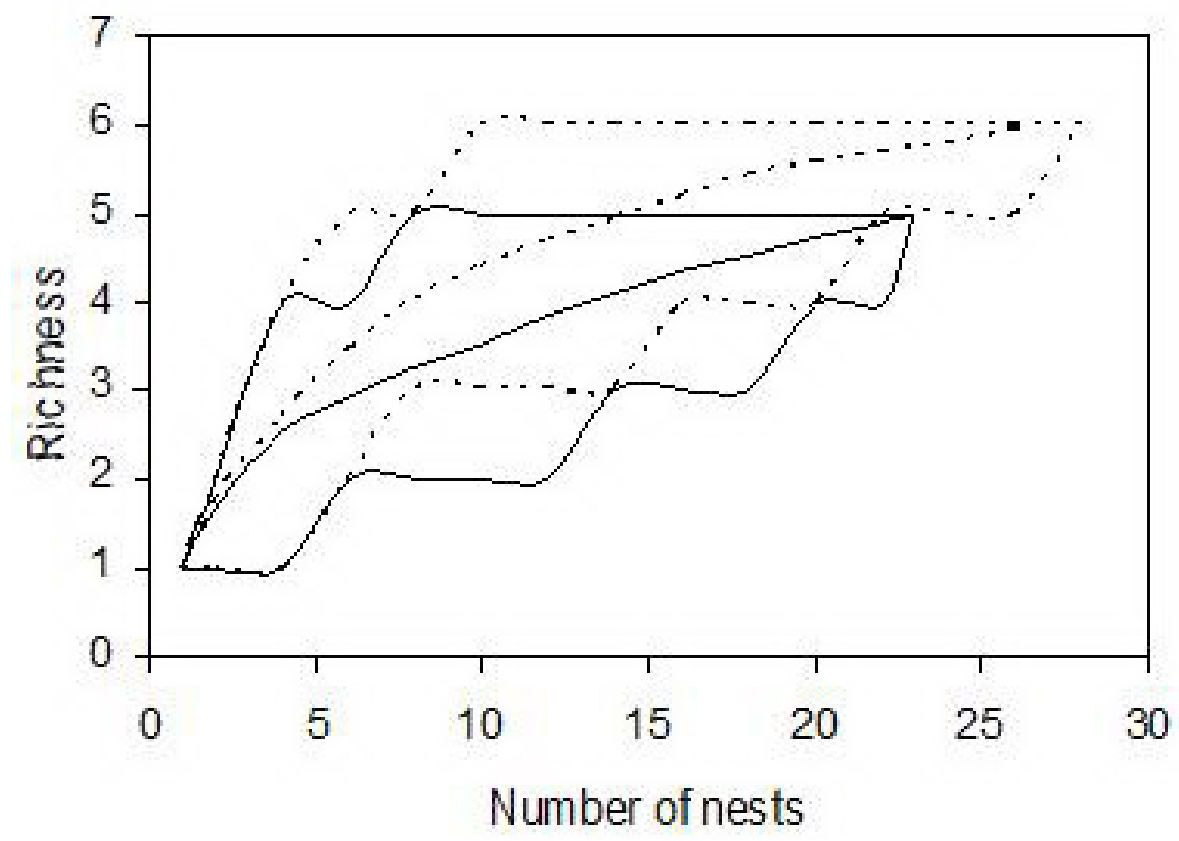

Figure 4. Nest-based rarefaction curves for the hot/wet and cool/dry seasons of the second year of study at Estação Ecológica de Paulo de Faria, Paulo de Faria, SP. Comparisons were made for 23 nests, 95\% confidence interval. Continuous line $=$ hot $/$ wet season; Dashed line $=$ cool $/$ dry season. 
The highest frequencies of nesting during the cool/dry season occurred in April in both years. During the hot/wet season, January and March in the first year and March and October in the second year were the months with the highest number of nests built. The nesting activities of $C$. analis, the most abundant species, did not differ between the hot/ wet and cool/dry seasons of the first year (Mann-Whitney test; $\mathrm{Z}=0.82 ; \mathrm{P}=0.410$ ), or the second year (Mann-Whitney test; $\mathrm{Z}=0.35 ; \mathrm{P}=0.720$ ) (Figure 5).

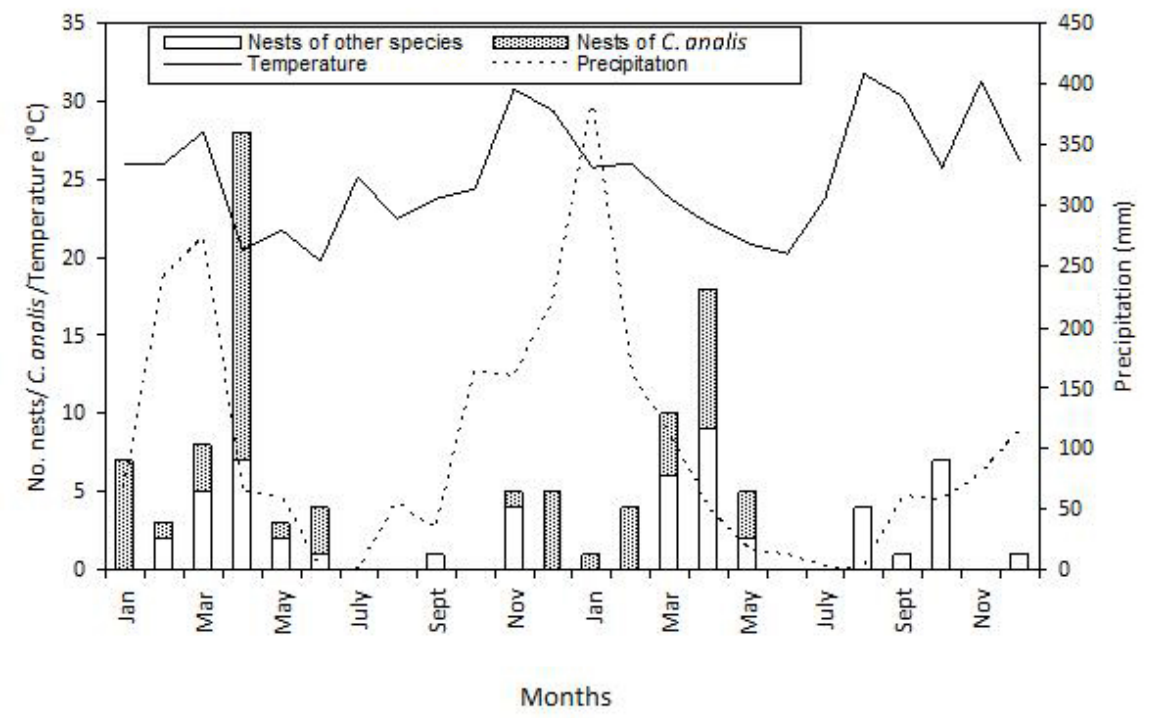

Figure 5. Number of nests constructed by Centris analis and by other species from January 1998 to December 1999 at Estação Ecológica de Paulo de Faria, Paulo de Faria, SP.

At SCF, the hot/wet and cool/dry seasons differed significantly in the values of temperature and precipitation, in both years (Mann-Whitney tests; $\mathrm{Z}=2.72 ; \mathrm{P}=0.006$ and $\mathrm{Z}=2.88 ; \mathrm{P}=0.0003$, for precipitation in the first and second years, respectively; $\mathrm{Z}=$ $2.88 ; \mathrm{P}=0.0003$ and $\mathrm{Z}=2.41 ; \mathrm{P}=0.001$, for temperature in the first and second years, respectively). The temperatures were similar in the cool/dry seasons of each year $(\mathrm{t}=-0.49$; $\mathrm{P}=0.629)$ as well as in the hot/wet seasons $(\mathrm{t}=0.26 ; \mathrm{P}=0.788)$. Although no significant difference in precipitation was observed between the cool/dry seasons of each year $(t=-0.03 ; P=0.975)$, it was significant higher in the hot/wet season of the second year than during the same season in the first year $(t=-2.29 ; \mathrm{P}=0.045)$. Bee species richness obtained by rarefaction for 90 nests, in the first year, and 100 nests, in the second year, was significantly lower during the cool/dry season of both years (3.9 species, 4-4, and 5.8 species, 5-6, 95\% confidence interval for both cases, for the first and second years, respectively) than that found for the hot/wet season (5.8 species, 5-6, and 7.7 species, $6-8,95 \%$ confidence interval for both cases, for the first and second years, respectively; Figures 6, 7). 


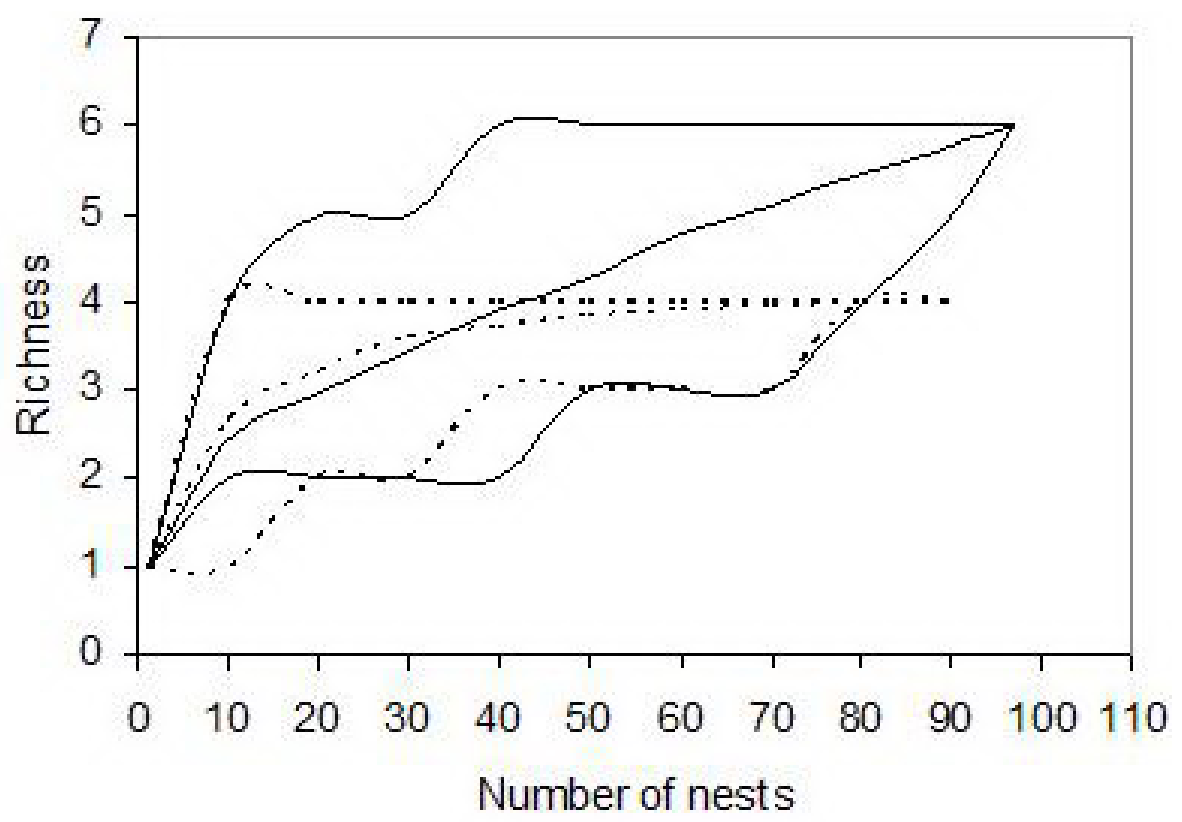

Figure 6. Nest-based rarefaction curves for the hot/wet and cool/dry seasons of the first year of study at Santa Cecília Farm, Patrocínio Paulista, SP. Comparisons were made for 90 nests, 95\% confidence interval. Continuous line $=$ hot $/$ wet season; Dashed line $=$ cool/dry season.

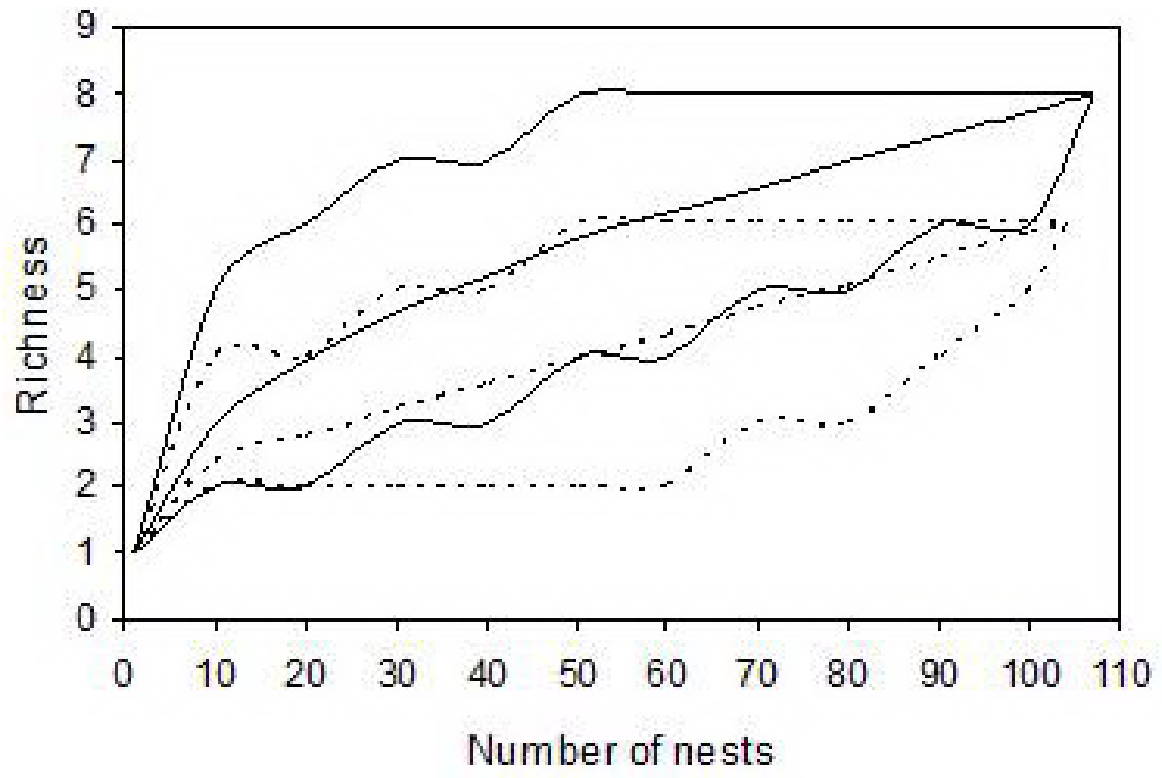

Figure 7. Nest-based rarefaction curves for the hot/wet and cool/dry seasons of the second year of study at Santa Cecília Farm, Patrocínio Paulista, SP. Comparisons were made for 100 nests, 95\% confidence interval. Continuous line $=$ hot $/$ wet season; Dashed line $=\mathrm{cool} /$ dry season. 
Nesting construction occurred throughout the study, except for March and July 2000, when no nests were built. In the cool/dry seasons the highest frequencies of nesting occurred in August 2000 and May 2001, while in the hot/wet seasons the peaks of nesting were observed in February 2001 and December 2001 (Figure 8). No significant difference was observed between the number of nests made during the hot/wet and cool/dry seasons of each year (Mann-Whitney tests; $\mathrm{Z}=-0.72 ; \mathrm{P}=0.467$, for the first year, and $\mathrm{Z}=-0.05 ; \mathrm{P}=0.952$, for the second year), between the total number of nests made during the cool/dry seasons of both years ( 92 and 96 nests in the first and the second years, respectively, Mann-Whitney test; $\mathrm{Z}=0.16 ; \mathrm{P}=0.871$ ) as well as during the hot/wet seasons of both years (110 and 115 nests in the first and the second years, respectively, $\mathrm{t}=-0.27 ; \mathrm{P}=0.788$ ). The two most abundant species, $C$. analis and T. diversipes, showed similar frequencies of nesting in each season of the year (Mann-Whitney tests; $\mathrm{Z}=$ $0.08 ; \mathrm{P}=0.935$ and $\mathrm{Z}=1.36 ; \mathrm{P}=0.172$, for $C$. analis for the first and second years, respectively; $\mathrm{Z}=0.40 ; \mathrm{P}=0.682$ and $\mathrm{Z}=-0.16 ; \mathrm{P}=0.870$, for $T$. diversipes for the first and second years, respectively). The nesting peaks of these species occurred in different months with a higher occupation of traps by C. analis in August 2000, February 2001, April 2001, and December 2001 while T. diversipes used the traps more frequently in July 2000 and May 2001 (Figure 8).

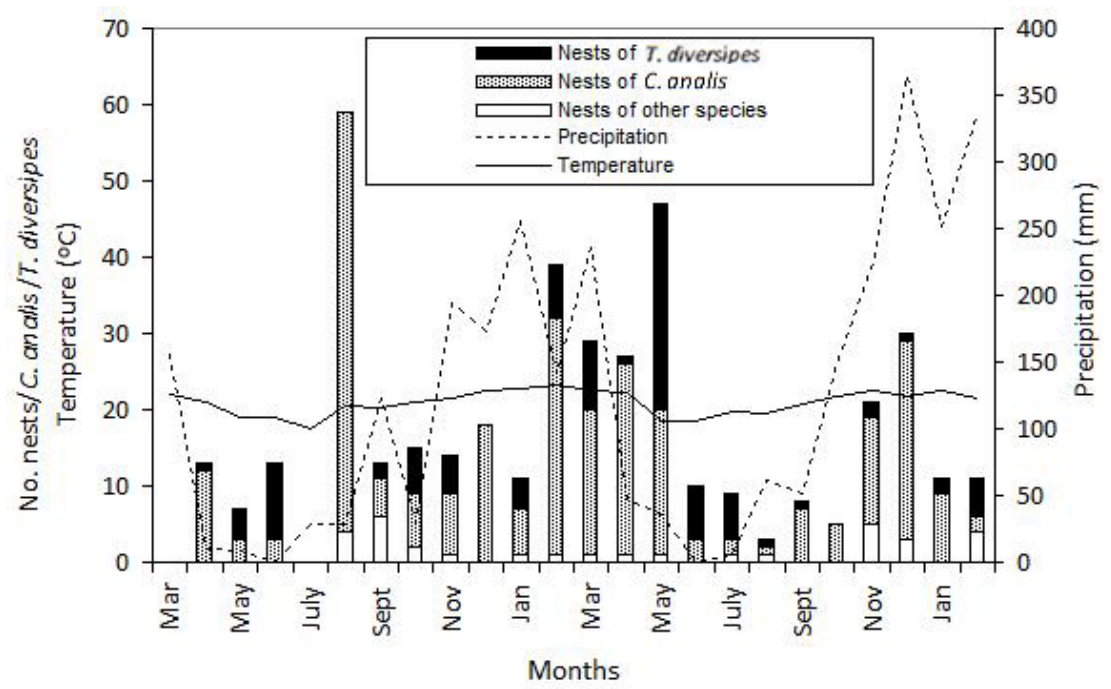

Figure 8. Number of nests constructed by Centris analis, Tetrapedia diversipes and by other species from March 2000 to February 2002 at Santa Cecília Farm, Patrocínio Paulista, SP.

\section{DISCUSSION}

The finding of most species with few nests and few species with many nests was observed in both collecting areas. Similar results were found in studies made in other forest fragments of the State of São Paulo (Camillo et al., 1995; Garófalo, 2000) as well as in habitats of other Brazilian states (Morato and Campos, 2000; Viana et al., 2001; Aguiar et al., 2005; Buschini, 2006), indicating that such differences in species abundance are shared by all communities. Comparisons of species richness obtained in studies made with trap-nests from 
different places may be complicated because of the differences in sampling methodology, types and arrangement of traps in the study area, availability of natural preexisting cavities, and sampling periods (Aguiar et al., 2005).

Although the communities that we studied had similar species richness, evidenced by rarefaction analysis, species accumulation curves showed notable differences between the areas during the two years of study. The curves for both communities appeared to be no saturated, and the observed tendencies suggest that an increase in the duration of the study could result in the sampling of other species at SCF faster than at EEPF. Comparing the results of our study to those obtained from other forest fragments of the State of São Paulo, the sampling methodology was the same (Camillo et al., 1995; Garófalo, 2000); consequently, we can conclude that EEPF and SCF are among the most species-poor communities since the lowest number of species occupying traps occurred at EEPF and the number of species at SCF was only higher than that observed at Estação Ecológica de Jataí, Luis Antonio ( $\mathrm{N}=11$ species).

Irrespective of the similarity in species richness, these communities differ strongly in species composition. Besides having been sampled only at EEPF, E. surinamensis, Centris sp and Megachile sp did not occupy traps in any other forest fragment studied in São Paulo State (Camillo et al., 1995; Garófalo, 2000). Similarly, Megachile (Pseudocentris) sp and S. marginatum occurred only at SCF. Of the eight species with low frequency of nesting, those building from one to nine nests, C. labrosa, T. rugulosa, and T. curvitarsis, were very well represented in the Serra do Japi, in Jundiaí, and in two habitats of the Santa Carlota Farm, in Cajuru, while the five remaining ones also occurred at low frequencies in other habitats $(\mathrm{Ca}-$ millo et al., 1995; Garófalo, 2000). On the other hand, C. analis, C. tarsata and T. diversipes, the most abundant species at EEPF and SCF, were sampled in all other studies made in forest fragments of the State of São Paulo, with the frequency of nesting by $C$. analis being always higher than that of $C$. tarsata, as we also observed in this study.

The significantly lower Shannon-Wiener diversity value obtained for SCF was a surprising result because of the great difference between the numbers of emerged individuals in both communities besides the finding of a larger number of species nesting there. However, as the Shannon-Wiener index takes into account species richness and species evenness values, the smaller the value of evenness, the smaller the diversity value (Krebs, 1989). So, since the species richness values were similar for these two communities, the distribution of emerged individuals by species at SCF was the factor that determined the value of the diversity for that community.

Most studies made in Brazil have shown that Centris species are usually those that nest at highest frequency in trap-nests (Camillo et al., 1995; Garófalo, 2000; Morato and Campos, 2000; Viana et al., 2001; Aguiar and Martins, 2002; Buschini, 2006). This pattern of occupation of traps was also observed in this study; but some exceptions have been found. In two studies carried out in forest urban remnants, one at the Estação Ecológica da Universidade Federal de Minas Gerais, Belo Horizonte, MG (Loyola and Martins, 2006), and the other on the campus of the University of São Paulo, SP (Alves-dos-Santos, 2003), Anthodioctes megachiloides (Megachilidae) was the most abundant species, followed by C. tarsata, in the first case, and $T$. diversipes, in the second case. The absence of $A$. megachiloides at EEPF and the few nests established at SCF may reinforce the suggestion by Loyola and Martins (2006) that the forest urban remnants should be preserved because they can be refuges for some species.

Fluctuations in annual frequencies and occurrence of seasonality in insects are population characteristics related to climatic factors and resource availability (Young, 1982; No- 
votny and Basset, 1998; Tommasi et al., 2004; Oertli et al., 2005) and have been reported by several authors (Camillo et al., 1995; Frankie et al., 1993, 1998; Morato et al., 1999; Pereira et al., 1999; Viana et al., 2001; Gazola and Garófalo, 2003; Aguiar and Garófalo, 2004; Aguiar et al., 2005; Thiele, 2005) working with trap-nests. Frankie et al. (1998) suggested that annual fluctuations are a normal characteristic of cavity-nesting bee species, and that different species would be affected differently by climatic changes between years. Although species richness was lower in the cool/dry season during both years at SCF, and in the first year at EEPF, and higher in the hot/wet seasons, the frequencies of nesting did not differ significantly between seasons, not only for the overall community but also for each of the most abundant species, $C$. analis, in both communities, and T. diversipes for SCF. This differs from what was reported from various studies (Camillo et al., 1995; Morato et al., 1999; Pereira et al., 1999; Gazola and Garófalo, 2003; Aguiar et al., 2005; Thiele, 2005) that found a strong relationship between nesting frequency and rainfall. No annual fluctuations in the frequencies of nesting in both communities and for each of the most abundant species, $C$. analis and $T$. diversipes, were observed. As the two environmental variables, temperature and precipitation, were not significantly different between the two years of study in each area, we conclude that climatic stability resulted in population stability.

Natural enemies attacking the immatures or stored food of trap-nesting bee species in Brazil have been reported in various studies (Pereira et al., 1999; Jesus and Garófalo, 2000; Aguiar and Martins, 2002; Alves-dos-Santos, 2003; Gazola and Garófalo, 2003; Aguiar and Garófalo, 2004; Aguiar et al., 2006); in most cases, these enemies belong to the same families and genera as those we found in this study. However, a lack of taxonomic knowledge on these insects has made it difficult to do comparative analyses. Of the 17 species of natural enemies associated with the bee species nesting in the two areas, only M. bicolor, C. aff. uhleri, L. cayennensis, C. (Cyrtocoelioxys) sp, and A. oedipus occurred both at EEPF and at SCF. These species attacked the same host species in both areas as well as different host species in different areas. Of the 12 remaining species, three occurred only at EEPF and the others were present only at SCF. The most abundant host species were those that had a higher number of natural enemies associated.

\section{ACKNOWLEDGMENTS}

We dedicate this paper to Dr. Warwick E. Kerr. We are grateful to J.C. Serrano for technical help, Carlos J.E. Lamas for the bombylid identifications, T. Griswold for the Coelioxys identification, D. Urban for the Anthidiini identification, P.C. Bispo for the advice on statistical analysis, the Instituto Florestal de São Paulo for permission to work at Estação Ecológica de Paulo de Faria, and the owners of the Fazenda Santa Cecília who kindly allowed us to have access to their land. A.L. Gazola received a grant from CAPES. Research supported by a grant from CNPq to C.A. Garófalo.

\section{REFERENCES}

Aguiar AJC and Martins CF (2002). Abelhas e vespas solitárias em ninhos-armadilha na Reserva Biológica Guaribas (Mamanguape, Paraíba, Brasil). Rev. Bras. Zool. 19: 101-116.

Aguiar CM and Garófalo CA (2004). Nesting biology of Centris (Hemisiella) tarsata Smith (Hymenoptera, Apidae, Centridini). Rev. Bras. Zool. 21: 477-486.

Aguiar CM, Garófalo CA and Almeida GF (2005). Trap-nesting bees (Hymenoptera, Apoidea) in areas of dry semideciduous 
forest and caatinga, Bahia, Brazil. Rev. Bras. Zool. 22: 1030-1038.

Aguiar CML, Garófalo CA and Almeida GF (2006). Nesting biology of Centris (Hemisiella) trigonoides Lepeletier (Hymenoptera, Apidae, Centridini). (Biologia da nidificação de Centris (Hemisiella) trigonoides Lepeletier (Hymenoptera, Apidae, Centridini). Rev. Bras. Zool. 23: 323-330.

Alves-dos-Santos I (2003). Trap-nesting bees and wasps on the University Campus in São Paulo, Southeastern Brazil (Hymenoptera, Aculeata). J. Kansas Entomol. Soc. 76: 328-334.

Alves-dos-Santos I, Melo GAR and Rozen JG Jr (2002). Biology and immature stages of the bee tribe Tetrapediini (Hymenoptera: Apidae). Am. Mus. Novitates 3377: 1-45.

Buschini MLT (2006). Species diversity and community structure in trap-nesting bees in Southern Brazil. Apidologie 37: $58-66$.

Camillo E (2005). Nesting biology of four Tetrapedia species in trap-nests (Hymenoptera: Apidae: Tetrapediini). Rev. Biol. Trop. 53: 175-186.

Camillo E, Garófalo CA, Serrano JC and Muccillo G (1995). Diversidade e abundância sazonal de abelhas e vespas solitárias em ninhos armadilhas (Hymenoptera, Apocrita, Aculeata). Rev. Bras. Entomol. 39: 459-470.

Couto RM and Camilo E (2007). Influence of temperature on the immatures mortality of Centris (Heterocentris) analis (Hymenoptera, Apidae, Centridini). (Influência da temperatura na mortalidade de imaturos de Centris (Heterocentris) analis (Hymenoptera, Apidae, Centridini). Iheringia Ser. Zool. 97: 51-55.

Davies KF, Margules CR and Lawrence JF (2000). Which traits of species predict population declines in experimental forest fragments? Ecology 81: 1450-1461.

Frankie GW, Newstrom L, Vinson SB and Barthel JF (1993). Nesting-habitat preferences of selected Centris bee species in Costa Rican dry Forest. Biotropica 25: 322-333.

Frankie GW, Thorp RW, Newstrom-Lloyd LE, Rizzardi MA, et al. (1998). Monitoring solitary bees in modified wildland habitats: implications for bee ecology and conservation. Environ. Entomol. 27: 1137-1148.

Garófalo CA (2000). Comunidades de Abelhas (Hymenoptera, Apoidea) que Utilizam Ninhos-armadilhas em Fragmentos de Matas do Estado de São Paulo. In: Anais do IV Encontro sobre Abelhas, Ribeirão Preto, 4: 121-128.

Garófalo CA, Camillo E, Serrano JC and Rebêlo JMM (1993). Utilization of trap nests by Euglossini species (Hymenoptera: Apidae). Rev. Bras. Biol. 53: 177-187.

Gazola AL and Garófalo CA (2003). Parasitic behavior of Leucospis cayennensis Westwood (Hymenoptera, Leucospidae) and rates of parasitism in populations of Centris (Heterocentris) analis (Fabricius) (Hymenoptera, Apidae, Centridini). J. Kansas Entomol. Soc. 76: 131-142.

Gotelli NJ and Entsminger GL (2004). EcoSim: Null models software for ecology. Version 7.0. Acquired Intelligence Inc. and Kesey-Bear, Jerico, VT 05465. Available at [http://garyentsminger.com/ecosim/index.htm]. Accessed May 16, 2005.

Hulbert SH (1971). The nonconcept of species diversity: a critique and alternative parameters. Ecology 52: 577-586.

Hutcheson K (1970). A test for comparing diversities based on the Shannon formula. J. Theor. Biol. 29: 151-154.

Jesus BMV and Garófalo CA (2000). Nesting behaviour of Centris (Heterocentris) analis (Fabricius) in southeastern Brazil (Hymenoptera, Apidae, Centridini). Apidologie 31: 503-515.

Klein AM, Steffan-Dewenter I and Tscharntke T (2006). Rain forest promotes trophic interactions and diversity of trapnesting Hymenoptera in adjacent agroforestry. J. Anim. Ecol. 75: 315-323.

Krebs CJ (1989). Ecological Methodology. Harper Collins Publishers Inc., New York.

Kruess A and Tscharntke T (2002). Grazing intensity and the diversity of grasshoppers, butterflies, and trap-nesting bees and wasps. Conserv. Biol. 16: 1570-1580.

Lewinsohn TM, Prado PIKL and Almeida AM (2001). Inventários Bióticos Centrados em Recursos: Insetos Fitófagos e Plantas Hospedeiras. In: Conservação da Biodiversidade em Ecossistemas Tropicais (Garay I and Dias B, eds.). Editora Vozes, Petrópolis, 174-189.

Loyola RD and Martins RP (2006). Trap-nest occupation by solitary wasps and bees (Hymenoptera: Aculeata) in a forest urban remanent. Neotrop. Entomol. 35: 41-48.

Ludwig A and Reynolds JF (1988). Statistical Ecology: a Primer on Methods and Computing. Interscience, New York. Magurram AE (2004). Ecological Diversity and its Measurements. Princeton University Press, Princeton.

Morato EF (2001). Efeitos de fragmentação florestal sobre vespas e abelhas solitárias na Amazônia Central. II. Estratificação vertical. Rev. Bras. Zool. 18: 737-747.

Morato EF and Campos LAO (2000). Efeitos da fragmentação florestal sobre vespas e abelhas solitárias em uma área da Amazônia Central. Rev. Bras. Zool. 17: 429-444.

Morato EF, Garcia MVB and Campos LAO (1999). Biologia de Centris Fabricius (Hymenoptera, Anthophoridae, Centridini) em matas contínuas e fragmentadas na Amazônia Central. Rev. Bras. Zool. 16: 1213-1222.

Morisita M (1959). Measuring of interspecific association and similarity between communities. Mem. Fac. Sci., Kyushu 
Univ. Ser. E, Biol. 6: 65-80.

Novotny V and Basset Y (1998). Seasonality of sap-sucking insects (Auchenorrhyncha, Hemiptera) feeding on Ficus (Moraceae) in a lowland rain forest in New Guinea. Oecologia 115: 514-522.

Oertli S, Müller A and Dorn S (2005). Ecological and seasonal patterns in the diversity of a species-rich bee assemblage (Hymenoptera: Apoidea: Apiformes). Eur. J. Entomol. 102: 53-63.

Pereira M, Garófalo CA, Camillo E and Serrano JC (1999). Nesting biology of Centris (Hemisiella) vittata Lepeletier in southeastern Brazil (Hymenoptera, Apidae, Centridini). Apidologie 30: 1-12.

Pielou EC (1966). An Introduction to Mathematical Ecology. John Wiley \& Sons, New York.

Purvis A and Hector A (2000). Getting the measure of biodiversity. Nature 405: 212-219.

Simberloff DS (1972). Properties of the rarefaction diversity measurement. Am. Nat. 106: 414-418.

Steffan-Dewenter I (2002). Landscape context affects trap-nesting bees, wasps, and their natural enemies. Ecol. Entomol. 27: 631-637.

Thiele R (2005). Phenology and nest site preferences of wood-nesting bees in a Neotropical lowland rain Forest. Stud. Neotrop. Fauna Environ. 40: 39-48.

Tommasi D, Miro A, Higo HA and Winston L (2004). Bee diversity and abundance in an urban setting. Can. Entomol. 136: $851-869$.

Tscharntke T, Gathmann A and Steffan-Dewenter I (1998). Bioindication using trap-nesting bees and wasps and their natural enemies: community structure and interactions. J. Appl. Ecol. 88: 592-599.

Tylianakis JM, Klein AM, Lozada T and Tcharntke T (2006). Spatial scale of observation affects $\alpha, \beta$ and $\gamma$ diversity of cavity-nesting bees and wasps across a tropical land-use gradient. J. Biogeogr. 33: 1295-1304.

Viana BF, Silva FO and Klenert AMP (2001). Solitary bees (Hymenoptera: Apoidea) in tropical sand dune: diversity and phyenology (Diversidade e sazonalidade de abelhas solitárias (Hymenoptera: Apoidea) em dunas litorâneas no nordeste do Brasil). Neotrop. Entomol. 30: 245-251.

Young AM (1982). Population Biology of Tropical Insects. Plenum Press, New York.

Zanette LRS, Martins RP and Ribeiro SP (2005). Effects of urbanization on Neotropical wasp and bee assemblages in a Brazilian metropolis. Landscape Urban Plann. 71: 105-121.

Zar JH (1984). Biostatistical Analysis. Prentice Hall, New Jersey.

Zillikens A and Steiner J (2004). Nest Architecture, life cycle and cleptoparasite of the Neotropical leaf-cutting bee Megachile (Chrysosarus) pseudanthidioides Moure (Hymenoptera: Megachilidae). J. Kansas Entomol. Soc. 77: 193-202. 